"Przegląd Prawa Konstytucyjnego" Nr $3(15) / 2013$

\title{
Recenzja
}

\section{Lech Jamróz, Skarga konstytucyjna. Wstępne rozpoznanie, Wydawnictwo Temida 2, Białystok 2011, ss. 259}

Etap wstępnej kontroli skarg konstytucyjnych jest kluczowy dla określenia stopnia ochrony konstytucyjnych praw podmiotowych jednostki. Osoby fizyczne i prawne mają zasadne oczekiwanie, że podjęte władcze rozstrzygnięcia dotyczące ich sfery wolności i praw będą opierały się na zgodnej z konstytucją podstawie prawnej. Gwarantuje im to art. 45 ust. 1 Konstytucji stanowiący o „sprawiedliwym” rozpoznaniu sprawy oraz art. 79 ust. 1 i art. 190 Konstytucji kreujące prawo do zapobiegania skutkom niekonstytucyjnej ingerencji w sferę wolności i praw. Skarga jest jednak subsydiarnym środkiem ochrony, musi odpowiadać licznym wymogom określonym w Konstytucji i ustawie o Trybunale Konstytucyjnym (dalej: ustawa o TK). Ich spełnienie nie jest łatwym zadaniem. Wiele skarg kierowanych do Trybunału nie odpowiada wymaganiom ustawowym. Skargi konstytucyjne muszą więc podlegać wstępnej kontroli, w toku której Trybunał Konstytucyjny eliminuje środki ochrony wolności i praw formalnie wadliwe. Jakkolwiek selekcja skarg jest niezbędna z punktu widzenia dostępności do Trybunału, omawiany etap postępowania skargowego wymaga wnikliwej oceny. Zbytnie sformalizowanie postępowania skargowego może bowiem prowadzić do faktycznego pozbawienia prawa do wniesienia skargi konstytucyjnej. Z powyższych względów niezbędne jest poddawanie stałej analizie trybunalskiego acquis wypracowywanego na wstępnym etapie kontroli skarg konstytucyjnych. Dlatego przedmiot badań podjętych przez Autora recenzowanej książki jest trafny, znajduje głębokie uzasadnienie ustrojowe i ma fundamentalne znaczenie dla realizacji ochrony praw człowieka. 
Systematyka książki wydaje się przejrzysta. Praca składa się z pięciu rozdziałów. Dwa pierwsze mają charakter generalny, trzy kolejne odnoszą się do poszczególnych przesłanek skargi konstytucyjnej. Prima facie taki układ treści nie budzi wątpliwości. Jednak, w mojej ocenie, systematyka książki jest daleka od ideału. Przede wszystkim nie jest jasne, dlaczego Autor wyeksponował trzy warunki formalne skargi konstytucyjnej, poświęcając im osobny rozdział, a pozostałe wymogi albo pobieżnie omówił w pierwszym rozdziale, albo pominął. Jest to niewątpliwe defekt pracy, gdyż w wielowątkowym procesie wstępnej kontroli skarg konstytucyjnych i przy mnogości powstających w jego toku wątpliwości i problemów ograniczenie się do kilku przesłanek może okazać się niewystarczające. Nadto brak szczegółowszej systematyki tekstu utrudnia również korzystanie z książki potencjalnym jej adresatom pełnomocnikom sporządzającym skargę konstytucyjną.

Pierwszy rozdział recenzowanego opracowania Model polskiej skargi konstytucyjnej na tle porównawczym wprowadza do tematu książki. Po ciekawej genezie skargi Autor dość syntetycznie przedstawia dwa rodzaje omawianego środka ochrony praw - skargi na akty stosowania prawa oraz skargi na akty tworzenia prawa. Nie ustrzega się jednak nieścisłości, gdyż dokonuje zbyt uproszczonej kwalifikacji hiszpańskiej amparo do bliżej niezdefiniowanego modelu skargi służącego „ochronie tylko pewnych kategorii praw określonych w Konstytucji” (s. 26). Formalnie zakres przedmiotowy amparo wynika jedynie z art. 53 ust. 2 Konstytucji Hiszpanii oraz art. 44 ust. 1 ustawy organicznej o Trybunale Konstytucyjnym ${ }^{1}$, jednak hiszpański Trybunał Konstytucyjny w orzecznictwie dokonał tak gruntownego poszerzenia zakresu rozpoznawanych skarg, że nieaktualne stało się twierdzenie o jego ograniczeniu przedmiotowym. Trybunał rozpoznawał np. skargi na naruszenie prawa własności czy wielu innych praw i wolności niewskazanych w art. 14-29 Konstytucji.

W kolejnej części książki pt.: Ogólna charakterystyka wstępnego rozpoznania skargi konstytucyjnej omawiając cel i zasady wstępnego rozpoznania skarg, Autor trafnie zauważa, że służy ono ochronie Trybunału przed napływem dużej liczby skarg bezzasadnych (s. 41). Słusznie podkreśla zasadę

Ley Orgánica 2/1979 del Tribunal Constitucional de 3 octubre (BOE núm. 239, de 5 de octubre). 
dyspozycyjności postępowania, jednak pomija przy tym istotny jej skutek możliwość cofnięcia skargi. Niedosyt budzi także omówienie zasady skargowości. Przydatne natomiast mogą okazać się rozważania przedstawiające wewnętrzny tryb pracy nad skargami (s. 51-55). Niestety, one także są niekompletne. Bardzo powierzchownie przedstawiono zagadnienie usuwania braków formalnych skargi. Autor nie dostrzega, że ten etap postępowania jest w istocie wydłużeniem procesu sporządzania skargi, ze wszystkimi tego konsekwencjami (w szczególności musi być dokonany przez pełnomocnika). Nie odnosi się do problemu doręczania pism procesowych na etapie wstępnego rozpoznania. Od strony materialnej pomija coraz wyraźniej dostrzegalną w orzecznictwie TK koncepcję nieusuwalnych braków skargi konstytucyjnej ${ }^{2}$. Zdawkowe jest odniesienie się do problematyki postanowień tymczasowych (s. 56).

Poprawna, ale niepełna jest druga część drugiego rozdziału. Jedynie na dziesięciu stronach opracowania Autor omawia przesłanki formalne złożenia skargi i analizuje kwestie: terminu wniesienia skargi, sposobu dokonania tej czynności, wynikające $\mathrm{z}$ art. 126 Kodeksu postępowania cywilnego wymogi pism procesowych, przymusu adwokacko-radcowskiego oraz obowiązkowych załączników skargi. Największym uchybieniem tej części pracy jest zlekceważenie problemu liczenia biegu terminu wniesienia skargi, w sytuacji gdy skarżący występuje o tzw. prawo ubogich. Jest to poważny problem w orzecznictwie wstępnej kontroli. Wystąpienie o pełnomocnika $\mathrm{z}$ urzędu często prowadzi do przekroczenia terminu określonego w art. 46 ustawy o TK. W praktyce wątpliwości budzi również sposób liczenia termi$\mathrm{nu}$, jego przekształcenie $\mathrm{z}$ terminu określonego w miesiącach na termin liczony w dniach, ocena kiedy pełnomocnik dowiedział się o ustanowieniu go pełnomocnikiem w sprawie. Nieomówiona a problematyczna jest również sytuacja, gdy pełnomocnik odmawia sporządzenia skargi konstytucyjnej z uwagi na stwierdzony przez siebie brak podstaw do jej wniesienia czy też wypadek zmiany pełnomocnika przez skarżącego bądź jego śmierci. Autor nie odnosi się do kwestii sposobu podpisywania skargi (tzw. parafa może okazać się niewystarczająca ${ }^{3}$ ), nie dostrzega także, że ustawa o TK wyma-

2 Zob. postanowienie TK z dnia 14 lipca 2009 r., Ts 104/09, OTK ZU nr 5/B/2010, poz. 359 .

3 Postanowienie TK z dnia 1 lipca 2008 r., Ts 270/07, OTK ZU nr 1/B/2009, poz. 39. 
ga, by pełnomocnik sporządził skargę, a jej wniesienie pozostawia samemu skarżącemu.

Drugi rozdział zawiera także określenie kręgu podmiotów legitymowanych do wnoszenia skarg konstytucyjnych. Podważam zasadność dołączenia tej części książki do rozdziału. Zakres podmiotowy skargi konstytucyjnej jest jedną z szeroko omówionych kwestii w orzecznictwie, a dodatkowo wywołuje liczne spory. Zasługuje na odrębną analizę. Zgadzam się natomiast z Lechem Jamrozem, że zdolność skargowa musi być postrzegana przez charakter naruszonych praw, których ochrony skarżący domaga się w skardze (s. 72-73). Dlatego też niesporne jest przyznanie prawa do skargi osobom prawnym. Zbyt optymistyczne (choć trafne) - wziąwszy pod uwagę postanowienie o sygn. Ts 256/09, w którym odmówił nadania biegu skardze konstytucyjnej partii politycznej z uwagi na brak zdolności skargowej jest założenie o możliwości wniesienia skargi przez ugrupowanie polityczne. Autor przedstawił część problemów związanych z podmiotową stroną skargi (s. 77-81), szkoda jednak, że nie pokusił się o sformułowanie na ich podstawie ogólnej konkluzji.

Trzeci rozdział pt.: Ostateczne orzeczenie jako przesłanka materialna skargi konstytucyjnej jest bardzo dobrą merytorycznie, a przy tym ciekawą częścią recenzowanej książki. Lech Jamróz trafnie odróżnia ostateczność orzeczenia od wymogu wyczerpania drogi prawnej. Dobrze, że eksponuje różnice między ostatecznym orzeczeniem a orzeczeniem chronologicznie ostatnim w sprawie, zwłaszcza że odrębności tej nie dostrzegają sami skarżący. Interesujące są rozważania poświęcone władczemu charakterowi orzeczenia, z wydaniem którego skarżący występuje ze skargą konstytucyjną. Czytając tę część pracy, można czuć niedosyt, gdy chodzi o wymóg kształtowania sytuacji prawnej skarżącego. Współcześnie wydaje się, że traci na znaczeniu podział na akty deklaratoryjne i konstytutywne i że powoli dezaktualizuje się trybunalskie acquis w zakresie, w jakim wyklucza wniesienie skargi konstytucyjnej w związku z wydaniem orzeczenia deklaratoryjnego.

Przedostatnia część pracy Zaskarżony akt prawny przesłanka materialna skargi konstytucyjnej dotyczy przedmiotu skargi. To także wyróżniający się merytorycznie fragment książki, w którym Autor wyczerpująco dekodował dostrzegalne w orzecznictwie TK problemy związane tak z zakresem rzeczowym, jak i temporalnym zaskarżanych aktów normatywnych. Słusznie więc 
Lech Jamróz zwraca uwagę na znaczenie teorii normatywności kwestionowanych aktów (s. 121-122). Dostrzega i aprobuje fundamentalną z punku widzenia poszerzenia zakresu ochrony praw podmiotowych linię orzeczniczą TK, w której Trybunał opowiada się za autonomicznym rozumieniem pojęcia „akt normatywny” użytego w art. 79 ust. 1 Konstytucji. Ukazuje często nieostre różnice między kwestionowaniem aktów prawnych a skarżeniem treści tych aktów nadanych im przez sądy. Być może nie dość mocno uwypuklił, że skarżący winien się wystrzegać sprowadzenia swoich zarzutów wyłącznie do jednostkowego sposobu, w jaki organ orzekający w jego sprawie zastosował kwestionowaną regulację prawną. W takiej bowiem sytuacji Trybunał Konstytucyjny może przyjąć, że skarga konstytucyjna jest $\mathrm{w}$ istocie próbą zakwestionowania orzeczenia, nie zaś aktu normatywnego, który był jego podstawą. Uzupełnieniem rozdziału czwartego mogłoby stać się dokładniejsze przeanalizowanie różnego rodzaju ustaw (ustawa implementująca prawo UE, budżetowa, regulująca stosunki między RP a kościołami i związkami wyznaniowymi) z punktu widzenia dopuszczalności ich kwestionowania w postępowaniu skargowym oraz podkreślenie, że określenie przedmiotu skargi nierzadko wymaga dekodowania normy prawnej z szeregu przepisów, a obowiązkiem skarżącego jest zakwestionowanie każdego z nich ${ }^{4}$.

Ostatni, piąty rozdział książki - Naruszenie prawa i wolności konstytucyjnej jako przesłanka materialna skargi konstytucyjnej - budzi niedosyt. Jest on zbyt mało wątkowy w porównaniu do wielości sytuacji występujących w orzecznictwie, które należałoby zakwalifikować jako niewskazanie sposobu naruszenia konstytucyjnych wolności lub praw (art. 47 ust. 1 pkt 2 ustawy o TK). Do kanonu rozważań w tym zakresie weszło już odniesienie się do możliwości powołania art. 2, art. 31 ust. 3 i art. 32 Konstytucji jako samoistnych wzorców kontroli. Autor poświęcił tej problematyce należną uwagę (s. 194-207). Przemilczał natomiast analogiczny problem wzorców kontroli określonych w art. 84 i art. 217 Konstytucji. To ewidentny błąd, gdyż kwestia ta doczekała się wydania postanowienia Trybunału w pełnym składzie ${ }^{5}$. Na uwagę zasługiwał art. 92 Konstytucji często (wadliwie) powoływany jako

4 Postanowienie TK z dnia 9 grudnia 2009 r., Ts 29/08, OTK ZU nr 6/B/2009, poz. 444.

Postanowienie TKz dnia 16 lutego 2009 r., Ts 202/06, OTKZU nr 1/B/2009, poz. 23. 
wzorzec samoistny. Ciekawe mogłyby okazać się rozważania o art. 18 Konstytucji ${ }^{6}$. Autor zdecydował się na wyodrębnienie problematyki art. 45 ust. 1 Konstytucji (z pominięciem zresztą wyroku SK 7/06). Takie wyróżnienie było podyktowane częstością powoływania tego przepisu przez skarżących. Jeśli takie kryterium miało decydować o szerszej analizie wzorca, to zdecydowanie brakuje rozważań o art. 64 Konstytucji. Uwadze Lecha Jamroza umknęła również kwestia relacji przepisów znajdujących się w I i II rozdziale Konstytucji, a dotyczących tej samej kwestii (art. 24 i art. 65, art. 18 i art. 71 Konstytucji). Na miejscu Autora rozbudowałbym również wątek o aktualności naruszenia, gdyż kwestia ta wciąż jawi się jako problematyczna.

Nie mam wątpliwości, że recenzowana książka jest ważnym głosem w dyskusji o wstępnym rozpoznaniu skarg konstytucyjnych. Wiele jej fragmentów może być pomocnych dla zrozumienia niełatwej materii warunków formalnych skarg konstytucyjnych. Przy czytaniu książki towarzyszyło mi jednak ciągłe wrażenie, że nie jest ona dostatecznie szczegółowa i że Autor pomija liczne wątki obecne i ważkie w obejmującym ponad 4500 postanowień orzecznictwie TK wydanym w toku wstępnej kontroli skarg konstytucyjnych. Mimo że Autorowi nie udało się w pełni oddać bogactwa problemów wstępnego rozpoznania skarg (termin, pełnomocnictwo i zakres czynności nim objętych, dopuszczalne wzorce kontroli, prawo ubogich, postanowienie tymczasowe, oczywista bezzasadność skargi) książka jest godna polecenia.

$\mathrm{Na}$ koniec pozwolę sobie nie zgodzić się z optymizmem Autora, który stwierdza, że „etap wstępnego rozpoznania w odniesieniu do skarg konstytucyjnych (...) spełnia swój cel”. Wydaje mi się, że celem nie jest eliminacja skarg konstytucyjnych, co do których istnieje choćby cień wątpliwości co do formalnej poprawności skargi. Orzecznictwo TK wydaje mi się zbyt rygorystyczne i prowadzi do znacznego ograniczenia prawa do wniesienia skargi konstytucyjnej. Jak wynika $z$ danych liczbowych, w okresie między 17 października 1997 r. a 31 grudnia 2011 r. do Trybunału Konstytucyjnego wpłynęło 3648 skarg konstytucyjnych. Do merytorycznego rozpoznania przekazano 684 z nich (nieco ponad 36\%), jednak wyrokiem zakończyło się jedynie

6 Zob. wyrok TK z dnia 11 maja 2011 r., SK 11/09 (OTKZU 4/A/2011, poz. 32), w którym Trybunał opowiada się za uznaniem art. 18 Konstytucji za źródło praw podmiotowych jednostki. 
281 spraw (7\% wszystkich skarg). Na 281 wyroków Trybunał stwierdził niekonstytucyjność przepisów w 101 przypadkach. Stanowi to zatem ledwie 2,61\% wszystkich skierowanych do TK skarg konstytucyjnych.

Jarosław Sułkowski ${ }^{7}$ Uniwersytet Łódzki

7 Autor jest stypendystą w ramach projektu „Kształcenie kadr dla potrzeb rynku flexicurity i gospodarki opartej na wiedzy - oferta kierunków nauk humanistyczno-społecznych UŁ”, współfinansowanego ze środków Unii Europejskiej w ramach Europejskiego Funduszu Społecznego. 